\title{
Potential information and target variables for UK monetary policy
}

\section{Hakan Berument \& Richard T. Froyen}

To cite this article: Hakan Berument \& Richard T. Froyen (1998) Potential information and target variables for UK monetary policy, Applied Economics, 30:4, 449-463, DOI: $10.1080 / 000368498325723$

To link to this article: http://dx.doi.org/10.1080/000368498325723

$$
\text { Published online: } 04 \text { Oct } 2010 .
$$

Submit your article to this journal $\pi$

LII Article views: 21

Q View related articles $\leftarrow$

7 Citing articles: 2 View citing articles 주다. 


\title{
Potential information and target variables for UK monetary policy
}

\author{
HAKAN BERUMENT and RICHARD T. FROYEN
}

Bilkent University, Ankara, Turkey and ${ }^{\ddagger}$ Department of Economics, CB\# 3305, Gardner Hall, University of North Carolina, Chapel Hill, NC 27599-3305, USA

The relationship between traditional monetary policy goal variables (nominal GDP, real GPD and the inflation rate) and a number of financial market variables is investigated. The question examined is which if any of these financial market variables (monetary aggregates, interest rates and interest rate spreads) are potentially useful as either information variables or intermediate targets. While the implications concerning the usefulness of the financial variables considered are pessimistic concerning nominal GDP, more robust relationships are found for real GDP and inflation. The latter finding is of interest given the current UK monetary policy strategy of inflation targeting. Our results are, however, more supportive of the usefulness of several financial variables as information variables than as intermediate targets.

\section{INTRODUCTION}

Monetary authorities in industrialized countries have employed a number of financial variables as either intermediate targets or information variables. This study investigates the relationship in the United Kingdom between nominal GDP, real GDP, inflation and a number of possible monetary policy target or information variables. In particular, we are interested in finding out which relationships remained stable over the years since 1979, a period of rapid innovation in financial markets. The question is of interest because only variables which have stable relationships with income and/or inflation are capable of playing important roles in monetary policy formation, a point on which we elaborate below.

There have been numerous studies of the money-income relationship in the United States and United Kingdom (as well as in other countries). Friedman and Schwartz (1982) is a noteworthy study of relationships among money, income and interest rates in the two countries over the past century. In recent years there have been a number of studies for the United States using vector autoregression and/or cointegration techniques to study the relationship between income (both nominal and real) and a number of financial variables: Bernanke and Blinder (1992), Feldstein and Stock (1994),
Friedman and Kuttner (1992), (1993), Ramey (1993) and Stock and Watson (1989). ${ }^{1}$ The results from these studies differ in significant respects. A finding of several recent studies (Friedman and Kuttner, 1992; 1993) is that the relationships between income (both real and nominal) and all the monetary aggregates break down in the 1980s. Friedman and Kuttner (1992) also find that monetary aggregates lose predictive power with respect to inflation in the post1979 period.

These studies find that the income-interest rate relationship does not deteriorate, but rather becomes stronger in the 1980s. They also find that a measure of the public-private interest rate spread has significant predictive power with respect to nominal and real GDP. With respect to inflation, Friedman and Kuttner (1992) find that interest rates lose their predictive power in the post-1979 period, while the interest rate spread generally has no predictive power.

With respect to the money-income relationship Ramey (1993) and Feldstein and Stock (1994) come to a different conclusion. They find that for the $M 2$ aggregate the money-income relationship remains robust with inclusion of data from the post-1979 period.

Our research examines whether there is evidence of any stable relationships between income and/or inflation and a number of financial variables in the United Kingdom. We

${ }^{1}$ Chrystal and MacDonald (1994) study the relationship between income and two monetary aggregates for the United Kingdom. Sims (1992) studies the money-income relationship for the G7 countries. 
look to see if there have been shifts in these relationships of the same type as in the United States. As noted above, relationships between income (or inflation) and various potential monetary policy targets or information variables are of importance in the design of an optimal monetary policy strategy. As Friedman and Kuttner (1992, p. 473) point out concerning monetary aggregates

From an information-variable perspective there is no point to the central bank reacting to fluctuations in money if those fluctuations bear no implications for subsequent movements in income and prices. From an intermediate-target perspective, there is even less point to making monetary policy as if controlling money were stochastically equivalent to controlling income and prices if in fact there is no relationship between them.

Which variables then, if any, are good candidates as monetary policy targets or information variables in the United Kingdom?

Our answer to this question is, in brief, that a number of financial variables do appear to have relationships with ultimate monetary policy goals that make these financial variables useful in policy formation. Our results indicate, however, that the role of these financial variables might more usefully be as information variables rather than as intermediate targets, for reasons that will be explained.

The paper is organized as follows. Section II explains the procedures we employ and examines the time series properties of the data. Section III presents the results of tests based on vector autoregressions. Section IV summarizes these results and further examines their implications for policy. Section V contains concluding comments.

\section{STATISTICAL PROCEDURES AND TIME SERIES PROPERTIES OF THE DATA}

\section{Procedures}

Granger causality is one criterion that has been widely employed in tests of money-income and money-inflation relationships. It is an appropriate methodology with regard to the choice of an information variable because there the concern is whether or not a given financial magnitude has predictive power with respect to a target variable. As Friedman and Kuttner (1992, p. 474) observe, this is the relevant criterion 'regardless of whether the information it contains reflects true causation, reverse causation based on anticipations, or mutual causation by some independent but unobserved influence'.

With regard to the choice of an intermediate target, however, the distinction made by Bernanke (1993) between the structural question and the forecasting question is relevant. Granger causality analysis is useful in answering the forecasting question. If, however, a financial variable is Granger causal with respect to a goal variable due, for example, to mutual causation by a third variable it would not be a desirable intermediate target. Once the central bank began to control the variable, its relationship with the third variable, and thus with the goal variable would break down; Goodhart's law would come into play.

Further information on whether the relationship between a given financial variable and income or inflation is structural, in the sense that it is important in the transmission mechanism of monetary policy actions, can be gained from variance decompositions. These are constructed from orthogonalized residuals and at least avoid 'third variable causality effects' for variables included in the VAR. By changing the set of included variables one can check for other 'third variable' effects. ${ }^{2}$

A third type of relationship that we explore between income or inflation and several financial variables is that of cointegration. There may exist long-run equilibrium relationships between financial variables and income and/or inflation which have important policy implications as discussed in Friedman and Kuttner (1992). Cointegration between a given monetary aggregate and nominal income would, for example, imply that 'base drift' should be avoided in targeting the aggregate because velocity disturbances are transitory. Moreover, the existence of cointegration among the variables in our system has implications for the proper specification of tests for short-run relationships among them.

\section{Time series properties of the data}

The financial variables we include in our VARs and cointegration tests are a monetary aggregate, chosen among $M O$ (the monetary base), $M 2$ and $M 4$; an interest rate, either the treasury bill rate $\left(R_{\mathrm{B}}\right)$ or call money rate $\left(R_{\mathrm{C}}\right)$; or an interest rate spread, either the call rate minus the bill rate or the base bank lending rate $\left(R_{\mathrm{L}}\right)$ minus the bill rate. ${ }^{3,4}$ Additionally, in some of our VARS we include a measure of government

\footnotetext{
${ }^{2}$ Variance decompositions, of course, have there own drawbacks including dependence on the ordering of the variables.

${ }^{3}$ As noted in the introduction, Bernanke and Blinder (1992) and Friedman and Kuttner (1992) find that the public-private spread, measured for the United States by the treasury bill-commercial paper rate spread has predictive power with respect to income. Movements in this spread are interpreted as measures of a risk premium or of credit rationing. Other research has focused on the spread between the federal funds rate and treasury bill rate as a measure of monetary policy stance. Moersch (1996) shows that this spread has predictive power with respect to industrial production in both the United States and United Kingdom (where the overnight interbank rate replaces the federal funds rate). We use the base bank lending rate minus the bill rate as a measure of the public-private spread and the call (overnight) rate minus the bill rate as a spread that measures the stance of monetary policy.

${ }^{4}$ The monetary base is used only in a limited number of our tests due to several breaks in this data series.
} 
expenditures $(G)$. As goal variables we consider nominal GDP and then, separately, real GDP $(R G D P)$ and consumer price inflation $(\dot{P})$. Data are quarterly for $1957: 1-1993: 4$, though sometimes a shorter period is considered due to data unavailability; details are given in footnote ${ }^{\text {a }}$ to Table 1 . In addition to considering this whole period we consider two subperiods: 1957:1-1979:2 and 1979:3-1993:4. The breakpoint in 1979 is chosen because it marks the shift in policy with the election of Margaret Thatcher which affected monetary and bank regulatory policy.

We begin by testing the series for the presence of unit roots. We use four tests: the Dickey-Fuller test (DF), the augmented Dickey-Fuller (ADF) test and the tests proposed by Phillips and Perron (1988) (P and P) and Stock and Watson (1988) (S and W). Table 1 reports results from these tests. Panels labelled A show test results where all series are expressed in log levels except for interest rates and interest rate spreads which are levels and the inflation variable which is the log first difference of the price level. A trend was not included in these tests. (Results including a deterministic time trend are given in Table A.1 of the appendix. ${ }^{5}$ ) With the exception of the inflation rate and interest rate spreads, these tests do not consistently reject the hypothesis of a unit root in the series using the four respective methods.

Each panel labelled B shows the results of the same unit root tests after differencing the logs (the level in the case of the interest rate) of the variables (therefore second differencing of the price level). The hypothesis of a second unit root is decisively rejected for almost all the series. An exception is the nominal GDP series where only the Dickey-Fuller test rejects the presence of a unit root and only for the whole period and second subperiod. The presence of a second unit root in the inflation rate and log first difference of real GDP, the components of the log first difference of GDP, is rejected in all cases except the second subperiod for real GDP. Thus the evidence seems most consistent with stationarity of the first difference of GDP.

The results in Table 1 indicate that the log levels (or levels in the case of interest rates) of all the series we examine with the exception of interest rate spreads and the inflation rate are nonstationary. There may, however, be stationary relationships among those that are nonstationary; cointegrating vectors may exist.

Cointegration requires the stationarity of a linear combination of nonstationary series. For example, if the logarithm of money $(M)$, income $(Y)$ and an interest rate $(R)$ are individually nonstationary but they follow a simple linear relation such as

$$
Y-\alpha-\beta M-\gamma R
$$

and this relationship is stationary for nonzero values of $\beta$ and $\gamma$ jointly, then these three variables are cointegrated. If the equation is stationary, this suggests that following disturbances to $M, Y$ or $R$ there will be an adjustment to restore the equilibrium relationship among these variables.

We investigate the presence of cointegration among the nonstationary variables in our system using the Johansen procedure. The variables included in the first system we consider are nominal $G P D$, a monetary aggregate ( $M 2$ or M4), a short-term interest rate $\left(R_{\mathrm{C}}\right)$ or, alternatively, one of the two interest rate spreads. The second system is a fourvariable system where nominal GDP is replaced by separate real GDP and inflation $(\dot{P})$ measures.

The inclusion of the GDP measures and monetary aggregates in tests for cointegration requires no explanation. Inclusion of the other time series does. Consider first the inclusion of the inflation rate which from Table 1 appears to be a stationary variable. Hansen and Juselius (1995), however, suggest that there are cases when it is useful to include stationary variables in applying the Johansen procedure. As they explain, 'Often, a stationary variable might a priori play an important role in a hypothetical cointegration relation, for instance, an inflation rate. In particular, variables with a high degree of autocorrelation, also called near-integrated variables, are often very important in establishing a sensible long-run relation. ${ }^{6}$

Next consider the nominal interest rate $\left(R_{\mathrm{C}}\right)$ [or alternatively $R_{\mathrm{B}}$, (see footnote 5)]. The test statistics in Table 1 do not reject the presence of a unit root in any of our interest rate measures. But if, as indicated by Table 1 inflation is $\mathrm{I}(0)$, then if the nominal interest rate is $\mathrm{I}(1)$, the real interest rate must be I(1) which is inconsistent with many conventional macroeconomic models. King et al. (1991), find evidence that for US data the real interest rate is nonstationary and give a real business cycle interpretation to this result. An alternative possibility is that although we cannot reject the possibility of a unit root in the interest rate series, they are in fact stationary though near-integrated. If the nominal interest rate is $\mathrm{I}(1)$, it should clearly be included in applying the Johansen procedure; if it is instead a near integrated variable the rationale for its inclusion would parallel that for inflation. The latter rationale also applies to the inclusion of interest rate spreads.

Table 2 reports values of Johansen's lambda max and trace statistics for a number of three variable systems. Table 3 presents the same statistics for systems where nominal GDP is replaced by real GDP and the inflation rate is added. ${ }^{7}$ The lambda max statistic tests the null hypothesis of $r$ cointegrating vectors against the alternative hypothesis

\footnotetext{
${ }^{5}$ The Appendix containing additional Tables is available from the authors on request.

${ }^{6}$ The UK inflation rate does appear to be highly autocorrelated. In a regression of inflation on its first five lagged values the sum of the coefficients is 0.85 and the value of the Ljung-Box $\mathrm{Q}$-statistic is $185.2(\mathrm{p}$ value $=0.00)$.

${ }^{7}$ Both tables report results of cointegration tests performed without the inclusion of a deterministic time trend. We have computed the same statistics with a trend included, with no substantive effect on the results. (These test results are given in Table A2 and A3, available from authors on request.)
} 
Test

$R_{\mathrm{B}}$

G

A. Log levels

Full sample

$\begin{array}{lcc}\text { DF } & -2.212 & -0.146 \\ \text { ADF } & -3.171^{*} & -1.902 \\ \text { P \& P } & -10.500 & -0.072 \\ \text { S \& W } & -10.720 & -0.910\end{array}$

$\begin{array}{rrr}-6.197 * * & -1.813 & 2.903 \\ -4.089^{* *} & -1.590 & -1.703 \\ -64.590^{* *} & -8.609 & 0.318 \\ -62.010^{* *} & -9.777 & -0.608\end{array}$

$R_{\mathrm{L}}-R_{\mathrm{B}}$

M2

M2

M4

$-4.002 * *$
$-4.417 * *$
$-27.310 *$
$-26.290 * *$

$\begin{array}{rr}2.515 & 0.508 \\ -3.314 * & -2.178 \\ 0.623 & 0.052 \\ 0.041 & -0.266\end{array}$

$$
R_{\mathrm{C}}
$$

$-1.653$

$-0.513$

$-1.206$

-2.688
-2.808

-2.808
-12.130

$-12.510$

$-83.87 * *$

B. Log first differences

Full sample

DF
ADF
P \& P

$-8.109 * *-18.790 * *$

$\mathrm{P} \& \mathrm{P}$

S \& W

$-10.440 * * \quad-8.109 * *$

$-7.815^{* *}-8.427 * *$

$-18.790 * *$

$-9.154 * *-3.197 *$

$-6.388^{* *}-2.368$

$-9.025 * *$

$-11.420 * *-6.309 * *$

$-5.620^{* *}$

$-13.130 * *-20.45^{* *}$

$-84.240 * *-179.8^{* *}-3.936^{* *}$

$-4.267 * *$

$-9.843 * *-15.19 * *$

$-98.140 * *-130.8 * *-66.030^{* *}$

$51.820 * *$

$-175.3^{* *}$

$\begin{array}{lllll}-122.6^{* *} & -70.79^{* *} & -188.3^{* *} & -91.070^{* *} & -11.410\end{array}$

A. Log levels

First subperiod

$\begin{array}{llcclr}\text { DF } & -1.696 & 2.160 & -4.094^{* *} & -0.315 & 14.240 \\ \text { ADF } & -3.801 * * & -3.061^{*} & -4.758^{* *} & -3.845^{* *} & 0.627 \\ \text { P \& P } & -8.013 & 0.997 & -27.320^{*} & -0.237 & 1.540 \\ \text { S \& W } & -7.374 & 0.161 & -28.960^{* *} & -0.079 & 1.358\end{array}$

$$
\begin{gathered}
-2.725 \\
-3.020 * \\
-13.480
\end{gathered}
$$

$-12.290$
2.832
-1.368
-1.368
1.240

0.690

2.853
-1.849
0.537
0.377

-0.029
-2.413
-0.048
-0.475

$-2.590-7.146 * *$

$-3.643^{* *}-4.119^{* *}$

$-11.630-76.81^{* *}$

$-10.480-57.68 * *$

B. Log first differences

First subperiod

DF
ADF
P \&

$-8.397^{* *}-6.051^{* *}-12.900^{* *}$

$-6.471 * *-6.942 * *-9.834 * *-6.247 * *-2.425$

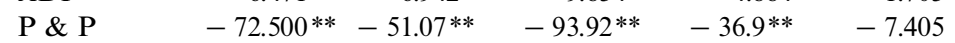

$\mathrm{S} \& \mathrm{~W}$

$-75.020 * *-34.55^{* *}$

$-103.7 * *$

$-44.25^{* *}$

$-6.559$
$-6.726^{* *}$
$-6.101 * *$
$-38.560 * *$

$-4.954 *$

$-5.53^{* *}$

$-2.999^{*}$

$-5.672 * *$
$-4.720^{* *}$
$-47.270 * *$

$-10.58 * *-16.36 * *$

$-8.355 * *-11.52 * *$

$-43.240^{* *}-80.1$ ** $-34.730^{* *}-46.310^{* *}$

$-80.660^{* *}-106.3^{* *}$

$-85.030 * *-110.5^{* *}$

A. Log levels

Second Subperiod

$\begin{array}{lrllll}\text { DF } & -1.515 & -2.485 & -6.142^{* *} & -1.100 & -7.400^{* *} \\ \text { ADF } & -2.059 & -2.629 & -3.578 & -1.850 & -1.217 \\ \text { P \& P } & -7.068 & -0.859 & -40.410^{* *} & -5.251 & -0.830 \\ \text { S \& W } & -11.750 & -0.869 & -33.05^{* *} & -8.181 & -0.815\end{array}$
$-4.827 * *$
$-3.840 * *$
$-33.54^{* *}$

$-3.026^{*}$
0.504
-0.868
-1.249

$\begin{aligned}- & 4.336^{* * *} \\ & 0.567 \\ - & 0.705 \\ - & 1.025\end{aligned}$

0.235
-3.113
-0.154
-0.621

$-1.969$

$-2.272$

$-9.207$

$-11.990$

$-6.608 * *$

$-41.66^{* *}$

$\begin{array}{ccc}-10.36 * * & -7.136 * * & -3.716^{* *} \\ -7.554 * * & -3.087^{*} & -2.343 \\ -62.39 * * & -73.9 * * & -22.84 * \\ -73.24 * * & -57.79 * * & -27.7 * *\end{array}$

-1.329
-1.285
-4.297

$-11.200$
$-8.167 * *-12.01 * *$
$-5.819^{* *} \quad-9.706 * *$
$-57.35^{* *}-66.86^{* *}$
$-59.41 * * \quad-89.17 * *$

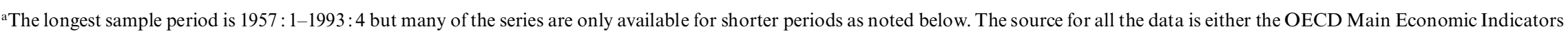

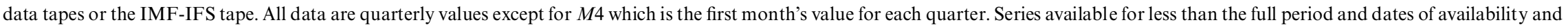

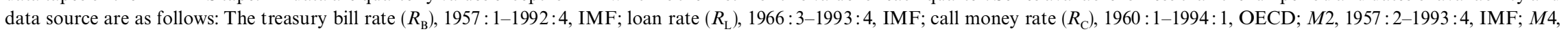

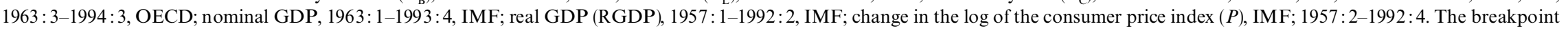
between the first and second subperiods is 1979:2.

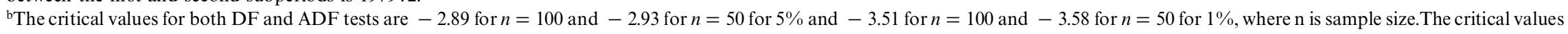

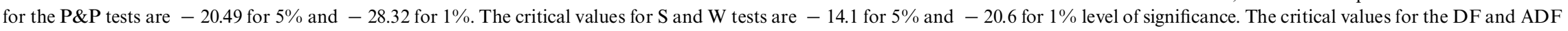
tests are from Harvey (1990), for the S and W test from Stock and Watson (1988), and for the P\&P test from Phillips and Ouliars (1990). 
Table 2. Johansen's cointegration tests among 3 variables: GDP, M2 or M4, and $R_{\mathrm{C}}, R_{\mathrm{C}}-R_{\mathrm{B}}$, or $R_{\mathrm{L}}-R_{\mathrm{B}}$ (without trend)

$\begin{array}{llllll}\mathrm{H}_{\mathrm{O}}: r=0 & \mathrm{H}_{\mathrm{O}}: r=1 & \mathrm{H}_{\mathrm{O}}: r=2 & \mathrm{H}_{\mathrm{O}}: r=0 & \mathrm{H}_{\mathrm{O}}: r \leqslant 1 & \mathrm{H}_{\mathrm{O}}: r \leqslant 2 \\ \mathrm{H}_{\mathrm{A}}: r=1 & \mathrm{H}_{\mathrm{A}}: r=2 & \mathrm{H}_{\mathrm{A}}: r=3 & \mathrm{H}_{\mathrm{A}}: r>0 & \mathrm{H}_{\mathrm{A}}: r>1 & \mathrm{H}_{\mathrm{A}}: r>2\end{array}$

Lambda Max

Lambda Trace

A. The $M 2$ aggregate

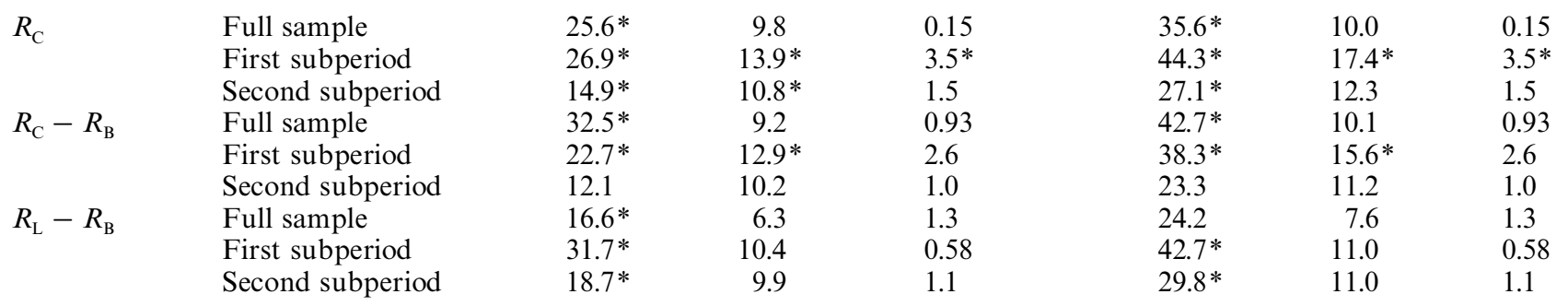

B. The $M 4$ aggregate

\begin{tabular}{|c|c|c|c|c|c|c|c|}
\hline \multirow[t]{3}{*}{$R_{\mathrm{C}}$} & Full sample & $22.2 *$ & 4.8 & 0.16 & $27.2 *$ & 5.0 & 0.16 \\
\hline & First subperiod & $30.5 *$ & $13.2 *$ & 2.2 & $45.9 *$ & $15.4 *$ & 2.2 \\
\hline & Second subperiod & $29.1 *$ & $14.7 *$ & 1.6 & $45.4 *$ & $16.3 *$ & 1.6 \\
\hline \multirow{3}{*}{$R_{\mathrm{C}}-R_{\mathrm{B}}$} & Full sample & $27.6^{*}$ & 5.7 & 0.75 & $34.0 *$ & 6.4 & 0.75 \\
\hline & First subperiod & $16.9 *$ & $14.0 *$ & 0.82 & $31.7 *$ & $14.8 *$ & 0.82 \\
\hline & Second subperiod & $25.1 *$ & 10.4 & 1.2 & $36.7 *$ & 11.6 & 1.2 \\
\hline \multirow[t]{3}{*}{$R_{\mathrm{L}}-R_{\mathrm{B}}$} & Full sample & $13.7 *$ & 5.9 & 1.6 & 21.2 & 7.5 & 1.6 \\
\hline & First subperiod & $21.7 *$ & 9.4 & 1.6 & $32.7 *$ & 11.0 & 1.6 \\
\hline & Second subperiod & $22.8 *$ & $14.5 *$ & 1.3 & $38.6 *$ & $15.8 *$ & 1.3 \\
\hline
\end{tabular}

*Indicates significance at $10 \%$ level.

of $(r+1)$ cointegrating vectors. The trace statistic is for a test of the null hypothesis that the number of cointegrating vectors is less than or equal to $r$ against the general alternative that there are more than $r$ vectors. In almost all cases, we can reject the null hypothesis of zero cointegrating vectors. For some systems, for some time periods, there is evidence of more than one cointegrating vector. ${ }^{8}$

\section{VECTOR AUTOREGRESSION TESTS}

The results in Tables 2 and 3 indicate cointegration among the nonstationary variables we consider. This argues for estimation of VARs in log levels with possible inclusion of a deterministic trend (see Sims et al. 1990), the approach we adopt.

\section{Tests of Granger causality}

We first present the results of Granger causality tests for the effects of various financial variables on nominal GDP. We then turn to specifications which include real GNP and the inflation rate as separate variables. We first discuss results using the $M 2$ and $M 4$ aggregates. Results using the monetary base $(M O)$ are discussed below.

Granger causality tests with respect to nominal GDP. Table 4 reports p-values of Granger causality tests for nominal GDP, where the p-value is the marginal significance level of the predictive value of a particular variable. Part A focuses on the M2 aggregate and Part B on M4. Results are given for the whole period and two subperiods where the exact dates of these samples are given in footnote ${ }^{\text {a }}$ to Table 1. Results are presented for estimates with and without the inclusion of a deterministic trend. The results in the table are for a threevariable unrestricted VAR containing a monetary aggregate, one interest rate or interest rate spread and nominal GDP, with four lags. ${ }^{9}$ We have also estimated a four-variable system where, following Friedman and Kuttner (1992) and several other studies, a measure of government expenditures is also included. These results are given in Table A.4 of

\footnotetext{
${ }^{8}$ We have also tested for cointegration when components of each interest rate spread are included as separate variables. Relative to the results given in Tables 2 and 3, results where the interest rates enter separately provide stronger support for the hypothesis of multiple cointegrating vectors. This is consistent with the existence of cointegration between the interest rates.

${ }^{9}$ We have also estimated both the three and four variable systems with eight lags. The results were quite similar to those in Tables 4 , 5 and 6.
} 
Table 3. Johansen's cointegration tests among 4 variables: $R G D P, \dot{P}, M 2$ or $M 4$, and $R_{\mathrm{C}}, R_{\mathrm{C}}-R_{\mathrm{B}}$, or $R_{\mathrm{L}}-R_{\mathrm{B}}($ without trend)

\begin{tabular}{cccccccc}
$\mathrm{H}_{\mathrm{O}}: r=0$ & $\mathrm{H}_{\mathrm{O}}: r=1$ & $\mathrm{H}_{\mathrm{O}}: r=2$ & $\mathrm{H}_{\mathrm{O}}: r=3$ & $\mathrm{H}_{\mathrm{O}}: r=0$ & $\mathrm{H}_{\mathrm{O}}: r \leqslant 1$ & $\mathrm{H}_{\mathrm{O}}: r \leqslant 2$ & $\mathrm{H}_{\mathrm{O}}: r \leqslant 3$ \\
$\mathrm{H}_{\mathrm{A}}: r=1$ & $\mathrm{H}_{\mathrm{A}}: r=2$ & $\mathrm{H}_{\mathrm{A}}: r=3$ & $\mathrm{H}_{\mathrm{A}}: r=4$ & $\mathrm{H}_{\mathrm{A}}: r>1$ & $\mathrm{H}_{\mathrm{A}}: r>1$ & $\mathrm{H}_{\mathrm{A}}: r>2$ & $\mathrm{H}_{\mathrm{A}}: r>3$ \\
\multicolumn{4}{c}{ Lambda Max } & & \multicolumn{5}{c}{ Lambda Trace } \\
\end{tabular}

A. The $M 2$ aggregate

$\begin{array}{llllrrrrrr}R_{\mathrm{C}} & \text { Full sample } & 37.5^{*} & 13.3 & 9.6 & 0.01 & 60.4^{*} & 22.9 & 9.6 & 0.01 \\ & \text { First subperiod } & 35.9^{*} & 21.6^{*} & 6.3 & 0.08 & 63.9^{*} & 28.0^{*} & 6.4 & 0.08 \\ R_{\mathrm{C}}-R_{\mathrm{B}} & \text { Second subperiod } & 38.8^{*} & 19.4^{*} & 12.7^{*} & 9.2^{*} & 80.2^{*} & 41.4^{*} & 22.0^{*} & 9.2^{*} \\ & \text { Full sample } & 32.8^{*} & 20.5^{*} & 11.4^{*} & 0.01 & 64.8^{*} & 31.9^{*} & 11.4 & 0.01 \\ & \text { First subperiod } & 24.8 & 20.4^{*} & 9.3 & 0.20 & 54.8^{*} & 29.9^{*} & 9.5 & 0.20 \\ R_{\mathrm{L}}-R_{\mathrm{B}} & \text { Second subperiod } & 27.4^{*} & 16.7^{*} & 13.8^{*} & 11.5^{*} & 69.4^{*} & 42.0^{*} & 25.2^{*} & 11.5^{*} \\ & \text { Full sample } & 19.7^{*} & 11.7 & 6.9 & 0.21 & 38.6 & 18.8 & 7.1 & 0.21 \\ & \text { First subperiod } & 20.4^{*} & 12.7 & 6.5 & 0.12 & 39.8 & 19.4 & 6.7 & 0.12 \\ & \text { Second subperiod } & 31.5^{*} & 18.3 * & 15.8^{*} & 7.4^{*} & 73.0^{*} & 41.6^{*} & 23.3 * & 7.4^{*}\end{array}$

B. The M4 aggregate

\begin{tabular}{|c|c|c|c|c|c|c|c|c|c|}
\hline \multirow[t]{3}{*}{$R_{\mathrm{C}}$} & Full sample & $31.5 *$ & 10.5 & 7.0 & 0.19 & $49.2 *$ & 17.7 & 7.2 & 0.2 \\
\hline & First subperiod & $20.8^{*}$ & $15.6^{*}$ & 6.9 & 0.08 & $43.5^{*}$ & 22.6 & 7.0 & 0.08 \\
\hline & Second subperiod & $42.3^{*}$ & $20.9 *$ & $12.1 *$ & $8.9 *$ & $83.9 *$ & $41.6^{*}$ & $20.8 *$ & $8.7 *$ \\
\hline \multirow[t]{3}{*}{$R_{\mathrm{C}}-R_{\mathrm{B}}$} & Full sample & $32.2 *$ & $14.6^{*}$ & 9.0 & 0.19 & $56.0^{*}$ & 23.8 & 9.2 & 0.19 \\
\hline & First subperiod & $24.8^{*}$ & $15.1 *$ & 7.9 & 0.05 & $47.9 *$ & 23.1 & 7.9 & 0.05 \\
\hline & Second subperiod & $33.9 *$ & $22.2 *$ & $15.6 *$ & $7.5^{*}$ & $79.2 *$ & $45.4^{*}$ & $23.1 *$ & $7.5 *$ \\
\hline \multirow[t]{3}{*}{$R_{\mathrm{L}}-R_{\mathrm{B}}$} & Full sample & $17.9 *$ & 10.9 & 6.0 & 0.29 & 35.0 & 17.2 & 6.3 & 0.29 \\
\hline & First subperiod & $21.1 *$ & 10.5 & 6.4 & 0.72 & 38.8 & 17.7 & 7.2 & 0.72 \\
\hline & Second subperiod & $36.1^{*}$ & $21.7 *$ & $17.4^{*}$ & $6.0 *$ & $81.3 *$ & $45.2 *$ & $23.4 *$ & $6.0 *$ \\
\hline
\end{tabular}

*Indicates significance at $10 \%$ level.

the Appendix and do not differ significantly from the results in Table $4 .^{10}$

The numbers in the row marked 'interest rate' refer to each of the four interest rates or spreads, as indicated in the column headings $\left(R_{\mathrm{B}}, R_{\mathrm{C}}, R_{\mathrm{C}}-R_{\mathrm{B}}\right.$ and $\left.R_{\mathrm{L}}-R_{\mathrm{B}}\right)$. The numbers in the $M 2$ or $M 4$ row refer to the marginal significance level of that aggregate in a VAR including the interest rate (or spread) in the respective column. A row giving $p$-values for the lags of GDP itself is not included because these values are always highly significant - zero to the three decimal places reported in the table - and therefore uninformative.

The results in the table have somewhat pessimistic implications concerning the usefulness of any of the financial variables we consider as robust information variables or intermediate targets for monetary policy. With either monetary aggregate included, the spread between the call money rate and treasury bill rate is informative with respect to GDP, with or without the inclusion of a time trend, in estimates for the whole sample and first-subperiod. This relationship, however, breaks down in the post-1979 sub- period. Depending on the interest rate or interest rate spread and on the time period, M2 and M4 in some cases have predictive value. This is more often the case in estimates for separate subperiods than for the whole period. Unlike the Friedman and Kuttner (1992) results for the United States, the money-income relationship, though not particularly robust in Table 4, does not appear to weaken in the post-1979 period.

Granger causality tests with respect to real GDP and inflation. In Tables 5 and 6 we present results for VARs where nominal $G D P$ is replaced by real $G D P(R G D P)$ and the inflation rate $(\dot{P})$. The tables are otherwise parallel to Table 4. Part A again focuses on the $M 2$ aggregate; Part $\mathrm{B}$ on M4. ${ }^{11}$

\section{Real GDP}

Table 5 shows a pattern quite different from that found by Friedman and Kuttner (1992) and Bernanke and Blinder (1992) for US data. The interest rate, whether measured by

\footnotetext{
${ }^{10}$ Alternative specifications include tax revenues as an additional variable or use the government deficit as a fiscal policy measure. These alternative fiscal policy variables appeared to have little causal effect on nominal GDP, real GDP or inflation. The government expenditure variable, while its inclusion did not significantly change our conclusions about the predictive value of the financial variables, did in a number of specifications have a significant effect.

${ }^{11}$ In Tables 5 and 6 we also do not show $p$ values for the own lags of the variables. Again those are always significant but not of interest.
} 
Table 4. Granger causality tests with respect to nominal GDP(log levels $)$

\begin{tabular}{|c|c|c|c|c|c|}
\hline Sample & Variable & $R_{\mathrm{B}}$ & $R_{\mathrm{C}}$ & $R_{\mathrm{C}}-R_{\mathrm{B}}$ & $R_{\mathrm{L}}-R_{\mathrm{B}}$ \\
\hline \multicolumn{6}{|c|}{ Part A. $M 2$ without trend } \\
\hline Full sample & $\begin{array}{l}\text { Interest rate } \\
M 2\end{array}$ & $\begin{array}{l}0.794 \\
0.972\end{array}$ & $\begin{array}{l}0.179 \\
0.891\end{array}$ & $\begin{array}{l}0.007 \\
0.753\end{array}$ & $\begin{array}{l}0.923 \\
0.951\end{array}$ \\
\hline First subperiod & $\begin{array}{l}\text { Interest rate } \\
\text { M2 }\end{array}$ & $\begin{array}{l}0.780 \\
0.127\end{array}$ & $\begin{array}{l}0.168 \\
0.022\end{array}$ & $\begin{array}{l}0.027 \\
0.385\end{array}$ & $\begin{array}{l}0.216 \\
0.013\end{array}$ \\
\hline Second subperiod & $\begin{array}{l}\text { Interest rate } \\
M 2\end{array}$ & $\begin{array}{l}0.197 \\
0.064\end{array}$ & $\begin{array}{l}0.170 \\
0.078\end{array}$ & $\begin{array}{l}0.641 \\
0.332\end{array}$ & $\begin{array}{l}0.938 \\
0.141\end{array}$ \\
\hline \multicolumn{6}{|l|}{$M 2$ with trend } \\
\hline Full sample & $\begin{array}{l}\text { Interest rate } \\
\text { M2 }\end{array}$ & $\begin{array}{l}0.799 \\
0.979\end{array}$ & $\begin{array}{l}0.217 \\
0.801\end{array}$ & $\begin{array}{l}0.020 \\
0.608\end{array}$ & $\begin{array}{l}0.838 \\
0.920\end{array}$ \\
\hline First subperiod & $\begin{array}{l}\text { Interest rate } \\
\text { M2 }\end{array}$ & $\begin{array}{l}0.227 \\
0.001\end{array}$ & $\begin{array}{l}0.137 \\
0.005\end{array}$ & $\begin{array}{l}0.056 \\
0.132\end{array}$ & $\begin{array}{l}0.368 \\
0.065\end{array}$ \\
\hline Second subperiod & $\begin{array}{l}\text { Interest rate } \\
M 2\end{array}$ & $\begin{array}{l}0.153 \\
0.087\end{array}$ & $\begin{array}{l}0.109 \\
0.102\end{array}$ & $\begin{array}{l}0.647 \\
0.345\end{array}$ & $\begin{array}{l}0.839 \\
0.184\end{array}$ \\
\hline \multicolumn{6}{|c|}{ Part B. $M 4$ without trend } \\
\hline Full sample & $\begin{array}{l}\text { Interest rate } \\
\text { M4 }\end{array}$ & $\begin{array}{l}0.842 \\
0.606\end{array}$ & $\begin{array}{l}0.281 \\
0.619\end{array}$ & $\begin{array}{l}0.017 \\
0.716\end{array}$ & $\begin{array}{l}0.871 \\
0.891\end{array}$ \\
\hline First subperiod & $\begin{array}{l}\text { Interest rate } \\
\text { M4 }\end{array}$ & $\begin{array}{l}0.282 \\
0.024\end{array}$ & $\begin{array}{l}0.278 \\
0.022\end{array}$ & $\begin{array}{l}0.041 \\
0.466\end{array}$ & $\begin{array}{l}0.258 \\
0.013\end{array}$ \\
\hline Second subperiod & $\begin{array}{l}\text { Interest rate } \\
\text { M4 }\end{array}$ & $\begin{array}{l}0.085 \\
0.016\end{array}$ & $\begin{array}{l}0.137 \\
0.039\end{array}$ & $\begin{array}{l}0.631 \\
0.216\end{array}$ & $\begin{array}{l}0.808 \\
0.065\end{array}$ \\
\hline \multicolumn{6}{|l|}{ M4 with trend } \\
\hline Full sample & $\begin{array}{l}\text { Interest rate } \\
\text { M4 }\end{array}$ & $\begin{array}{l}0.826 \\
0.687\end{array}$ & $\begin{array}{l}0.250 \\
0.520\end{array}$ & $\begin{array}{l}0.011 \\
0.274\end{array}$ & $\begin{array}{l}0.816 \\
0.909\end{array}$ \\
\hline First subperiod & $\begin{array}{l}\text { Interest rate } \\
\text { M4 }\end{array}$ & $\begin{array}{l}0.261 \\
0.045\end{array}$ & $\begin{array}{l}0.294 \\
0.071\end{array}$ & $\begin{array}{l}0.049 \\
0.568\end{array}$ & $\begin{array}{l}0.369 \\
0.206\end{array}$ \\
\hline Second subperiod & $\begin{array}{l}\text { Interest rate } \\
\text { M4 }\end{array}$ & $\begin{array}{l}0.188 \\
0.056\end{array}$ & $\begin{array}{l}0.241 \\
0.122\end{array}$ & $\begin{array}{l}0.633 \\
0.187\end{array}$ & $\begin{array}{l}0.673 \\
0.068\end{array}$ \\
\hline
\end{tabular}

the Treasury bill rate or call rate, as well as the call rate-bill rate spread $\left(R_{\mathrm{C}}-R_{\mathrm{B}}\right)$ have significant predictive power with respect to $R G D P$ for the whole period and first subperiod in most specifications in the table. This relationship, however, is not present in the second subperiod. The only exception being the call rate-bill rate spread when the M4 is the aggregate. The two monetary aggregates, on the other hand, show little sign of predictive power for the whole period or first subperiod, but are highly significant in the second subperiod. The monetary aggregate (M2 or $M 4)$ is significant at the $10 \%$ level in all 16 specifications in the table for the second subperiod and at the $1 \%$ level for all eight where $M 4$ is the aggregate.

\section{Inflation}

Table 6 provides results of Granger causality tests with respect to inflation. A very robust relationship is that be- tween the interest rate measures, with little to choose between $R_{\mathrm{B}}$ and $R_{\mathrm{C}}$, and inflation. This is true for the whole period and, unlike the result in Tables 4 and 5, for both subperiods. The interest rate spreads are sometimes significant, but their effect is less robust, depending on whether a trend is included and on which monetary aggregate is in the VAR.

The $M 2$ aggregate also has robust predictive value with respect to inflation. The $M 4$ aggregate is significant across all time periods, but its significance declines markedly in many specifications when a trend is included in the VAR. ${ }^{12}$

Results where the monetary base is the aggregate. As noted previously, we have also conducted Granger causality tests where money is measured by the monetary base. A difficulty for this analysis is that there are several breaks in the quarterly UK series for the base. The longest consistent series available runs from 1963:4 to 1986:3. This cuts off

\footnotetext{
${ }^{12}$ Results analogous to those in Tables 5 and 6 for the case where government spending is included as an additional variable are given in Tables A5 and A6 of the Appendix, available from the authors on request.
} 
Table 5. Granger causality tests with respect to real GDP (log levels)

\begin{tabular}{|c|c|c|c|c|c|}
\hline Sample & Variable & $R_{\mathrm{B}}$ & $R_{\mathrm{C}}$ & $R_{\mathrm{C}}-R_{\mathrm{B}}$ & $R_{\mathrm{L}}-R_{\mathrm{B}}$ \\
\hline \multicolumn{6}{|c|}{ Part A. $M 2$ without trend } \\
\hline Full sample & $\begin{array}{l}\text { Interest rate } \\
M 2 \\
\dot{P}\end{array}$ & $\begin{array}{l}0.007 \\
0.392 \\
0.999\end{array}$ & $\begin{array}{l}0.011 \\
0.208 \\
0.974\end{array}$ & $\begin{array}{l}0.045 \\
0.638 \\
0.719\end{array}$ & $\begin{array}{l}0.167 \\
0.532 \\
0.954\end{array}$ \\
\hline First subperiod & $\begin{array}{l}\text { Interest rate } \\
M 2 \\
\dot{P}\end{array}$ & $\begin{array}{l}0.023 \\
0.428 \\
0.945\end{array}$ & $\begin{array}{l}0.025 \\
0.206 \\
0.347\end{array}$ & $\begin{array}{l}0.008 \\
0.398 \\
0.521\end{array}$ & $\begin{array}{l}0.291 \\
0.666 \\
0.628\end{array}$ \\
\hline Second subperiod & $\begin{array}{l}\text { Interest rate } \\
M 2 \\
\dot{P}\end{array}$ & $\begin{array}{l}0.936 \\
0.044 \\
0.534\end{array}$ & $\begin{array}{l}0.715 \\
0.050 \\
0.313\end{array}$ & $\begin{array}{l}0.548 \\
0.063 \\
0.231\end{array}$ & $\begin{array}{l}0.742 \\
0.059 \\
0.235\end{array}$ \\
\hline \multicolumn{6}{|l|}{$M 2$ with trend } \\
\hline Full sample & $\begin{array}{l}\text { Interest rate } \\
M 2 \\
\dot{P}\end{array}$ & $\begin{array}{l}0.002 \\
0.128 \\
0.838\end{array}$ & $\begin{array}{l}0.001 \\
0.130 \\
0.870\end{array}$ & $\begin{array}{l}0.079 \\
0.359 \\
0.881\end{array}$ & $\begin{array}{l}0.243 \\
0.894 \\
0.955\end{array}$ \\
\hline First subperiod & $\begin{array}{l}\text { Interest rate } \\
M 2 \\
\dot{P}\end{array}$ & $\begin{array}{l}0.179 \\
0.331 \\
0.931\end{array}$ & $\begin{array}{l}0.041 \\
0.239 \\
0.538\end{array}$ & $\begin{array}{l}0.006 \\
0.082 \\
0.867\end{array}$ & $\begin{array}{l}0.734 \\
0.727 \\
0.590\end{array}$ \\
\hline Second subperiod & $\begin{array}{l}\text { Interest rate } \\
M 2 \\
\dot{P}\end{array}$ & $\begin{array}{l}0.929 \\
0.039 \\
0.603\end{array}$ & $\begin{array}{l}0.727 \\
0.045 \\
0.459\end{array}$ & $\begin{array}{l}0.497 \\
0.050 \\
0.343\end{array}$ & $\begin{array}{l}0.777 \\
0.056 \\
0.387\end{array}$ \\
\hline \multicolumn{6}{|c|}{ Part B. $M 4$ without trend } \\
\hline Full sample & $\begin{array}{l}\text { Interest rate } \\
\text { M4 } \\
\dot{P}\end{array}$ & $\begin{array}{l}0.007 \\
0.127 \\
0.845\end{array}$ & $\begin{array}{l}0.017 \\
0.058 \\
0.940\end{array}$ & $\begin{array}{l}0.073 \\
0.469 \\
0.798\end{array}$ & $\begin{array}{l}0.238 \\
0.512 \\
0.876\end{array}$ \\
\hline First subperiod & $\begin{array}{l}\text { Interest rate } \\
\text { M4 } \\
\dot{P}\end{array}$ & $\begin{array}{l}0.148 \\
0.406 \\
0.682\end{array}$ & $\begin{array}{l}0.097 \\
0.095 \\
0.245\end{array}$ & $\begin{array}{l}0.029 \\
0.161 \\
0.444\end{array}$ & $\begin{array}{l}0.591 \\
0.813 \\
0.797\end{array}$ \\
\hline Second subperiod & $\begin{array}{l}\text { Interest rate } \\
\text { M4 } \\
\dot{P}\end{array}$ & $\begin{array}{l}0.769 \\
0.011 \\
0.679\end{array}$ & $\begin{array}{l}0.260 \\
0.005 \\
0.222\end{array}$ & $\begin{array}{l}0.069 \\
0.002 \\
0.101\end{array}$ & $\begin{array}{l}0.198 \\
0.004 \\
0.149\end{array}$ \\
\hline \multicolumn{6}{|l|}{ M4 with trend } \\
\hline Full sample & $\begin{array}{l}\text { Interest rate } \\
\text { M4 } \\
\dot{P}\end{array}$ & $\begin{array}{l}0.007 \\
0.498 \\
0.812\end{array}$ & $\begin{array}{l}0.007 \\
0.343 \\
0.867\end{array}$ & $\begin{array}{l}0.095 \\
0.422 \\
0.842\end{array}$ & $\begin{array}{l}0.311 \\
0.832 \\
0.857\end{array}$ \\
\hline First subperiod & $\begin{array}{l}\text { Interest rate } \\
\text { M4 } \\
\dot{P}\end{array}$ & $\begin{array}{l}0.208 \\
0.528 \\
0.610\end{array}$ & $\begin{array}{l}0.077 \\
0.259 \\
0.319\end{array}$ & $\begin{array}{l}0.007 \\
0.102 \\
0.494\end{array}$ & $\begin{array}{l}0.799 \\
0.935 \\
0.786\end{array}$ \\
\hline Second subperiod & $\begin{array}{l}\text { Interest rate } \\
\text { M4 } \\
\dot{P}\end{array}$ & $\begin{array}{l}0.669 \\
0.008 \\
0.725\end{array}$ & $\begin{array}{l}0.262 \\
0.004 \\
0.333\end{array}$ & $\begin{array}{l}0.060 \\
0.001 \\
0.178\end{array}$ & $\begin{array}{l}0.225 \\
0.004 \\
0.266\end{array}$ \\
\hline
\end{tabular}

half of the post-1979 period, which is important to our study of the robustness of money-income relationships.

We therefore restrict discussion to the following two comments. (Results from Granger tests using three and four variable VARs analogous to those in Tables 4-6 are given in Tables A7-A9 of the Appendix.)
1. The base does not have robust predictive power with respect to nominal GDP, real GDP or the inflation rate. This result follows for the whole period and both subperiods.

2. Inferences about the predictive power of interest rates or interest rate spreads drawn on the basis of VARs where 
Table 6. Granger causality tests with respect to inflation (log levels)

\begin{tabular}{|c|c|c|c|c|c|}
\hline Sample & Variable & $R_{\mathrm{B}}$ & $R_{\mathrm{C}}$ & $R_{\mathrm{C}}-R_{\mathrm{B}}$ & $R_{\mathrm{L}}-R_{\mathrm{B}}$ \\
\hline \multicolumn{6}{|c|}{ Part A. $M 2$ without trend } \\
\hline Full sample & $\begin{array}{l}\text { Interest rate } \\
M 2 \\
R G D P\end{array}$ & $\begin{array}{l}0.005 \\
0.005 \\
0.048\end{array}$ & $\begin{array}{l}0.020 \\
0.008 \\
0.111\end{array}$ & $\begin{array}{l}0.064 \\
0.011 \\
0.204\end{array}$ & $\begin{array}{l}0.030 \\
0.004 \\
0.009\end{array}$ \\
\hline First subperiod & $\begin{array}{l}\text { Interest rate } \\
M 2 \\
R G D P\end{array}$ & $\begin{array}{l}0.006 \\
0.002 \\
0.612\end{array}$ & $\begin{array}{l}0.017 \\
0.001 \\
0.531\end{array}$ & $\begin{array}{l}0.036 \\
0.000 \\
0.566\end{array}$ & $\begin{array}{l}0.009 \\
0.002 \\
0.463\end{array}$ \\
\hline Second subperiod & $\begin{array}{l}\text { Interest rate } \\
M 2 \\
R G D P\end{array}$ & $\begin{array}{l}0.005 \\
0.000 \\
0.000\end{array}$ & $\begin{array}{l}0.025 \\
0.001 \\
0.000\end{array}$ & $\begin{array}{l}0.495 \\
0.006 \\
0.000\end{array}$ & $\begin{array}{l}0.599 \\
0.007 \\
0.003\end{array}$ \\
\hline \multicolumn{6}{|l|}{$M 2$ with trend } \\
\hline Full sample & $\begin{array}{l}\text { Interest rate } \\
M 2 \\
R G D P\end{array}$ & $\begin{array}{l}0.010 \\
0.030 \\
0.021\end{array}$ & $\begin{array}{l}0.038 \\
0.022 \\
0.063\end{array}$ & $\begin{array}{l}0.214 \\
0.013 \\
0.203\end{array}$ & $\begin{array}{l}0.046 \\
0.045 \\
0.011\end{array}$ \\
\hline First subperiod & $\begin{array}{l}\text { Interest rate } \\
M 2 \\
R G D P\end{array}$ & $\begin{array}{l}0.122 \\
0.004 \\
0.561\end{array}$ & $\begin{array}{l}0.075 \\
0.001 \\
0.279\end{array}$ & $\begin{array}{l}0.295 \\
0.000 \\
0.483\end{array}$ & $\begin{array}{l}0.208 \\
0.020 \\
0.552\end{array}$ \\
\hline Second subperiod & $\begin{array}{l}\text { Interest rate } \\
M 2 \\
R G D P\end{array}$ & $\begin{array}{l}0.001 \\
0.011 \\
0.000\end{array}$ & $\begin{array}{l}0.013 \\
0.074 \\
0.000\end{array}$ & $\begin{array}{l}0.664 \\
0.108 \\
0.001\end{array}$ & $\begin{array}{l}0.572 \\
0.075 \\
0.002\end{array}$ \\
\hline \multicolumn{6}{|c|}{ Part B. $M 4$ without trend } \\
\hline Full sample & $\begin{array}{l}\text { Interest rate } \\
M 4 \\
R G D P\end{array}$ & $\begin{array}{l}0.007 \\
0.020 \\
0.062\end{array}$ & $\begin{array}{l}0.015 \\
0.035 \\
0.052\end{array}$ & $\begin{array}{l}0.074 \\
0.089 \\
0.206\end{array}$ & $\begin{array}{l}0.025 \\
0.010 \\
0.025\end{array}$ \\
\hline First subperiod & $\begin{array}{l}\text { Interest rate } \\
M 4 \\
R G D P\end{array}$ & $\begin{array}{l}0.004 \\
0.069 \\
0.991\end{array}$ & $\begin{array}{l}0.001 \\
0.021 \\
0.534\end{array}$ & $\begin{array}{l}0.036 \\
0.080 \\
0.951\end{array}$ & $\begin{array}{l}0.009 \\
0.017 \\
0.213\end{array}$ \\
\hline Second subperiod & $\begin{array}{l}\text { Interest rate } \\
M 4 \\
R G D P\end{array}$ & $\begin{array}{l}0.000 \\
0.000 \\
0.000\end{array}$ & $\begin{array}{l}0.008 \\
0.002 \\
0.000\end{array}$ & $\begin{array}{l}0.378 \\
0.026 \\
0.002\end{array}$ & $\begin{array}{l}0.340 \\
0.020 \\
0.018\end{array}$ \\
\hline \multicolumn{6}{|l|}{$M 4$ with trend } \\
\hline Full sample & $\begin{array}{l}\text { Interest rate } \\
M 4 \\
R G D P\end{array}$ & $\begin{array}{l}0.012 \\
0.238 \\
0.072\end{array}$ & $\begin{array}{l}0.024 \\
0.188 \\
0.059\end{array}$ & $\begin{array}{l}0.124 \\
0.128 \\
0.253\end{array}$ & $\begin{array}{l}0.038 \\
0.110 \\
0.031\end{array}$ \\
\hline First subperiod & $\begin{array}{l}\text { Interest rate } \\
M 4 \\
R G D P\end{array}$ & $\begin{array}{l}0.084 \\
0.161 \\
0.862\end{array}$ & $\begin{array}{l}0.003 \\
0.019 \\
0.085\end{array}$ & $\begin{array}{l}0.530 \\
0.055 \\
0.734\end{array}$ & $\begin{array}{l}0.173 \\
0.108 \\
0.187\end{array}$ \\
\hline Second subperiod & $\begin{array}{l}\text { Interest rate } \\
M 4 \\
R G D P\end{array}$ & $\begin{array}{l}0.000 \\
0.010 \\
0.000\end{array}$ & $\begin{array}{l}0.004 \\
0.177 \\
0.000\end{array}$ & $\begin{array}{l}0.413 \\
0.359 \\
0.001\end{array}$ & $\begin{array}{l}0.338 \\
0.254 \\
0.013\end{array}$ \\
\hline
\end{tabular}

money is measured by the $M 2$ or $M 4$ aggregate are not changed substantially when the monetary base is substituted as the monetary aggregate.

\section{Implications of variance decompositions}

As explained in Section II, another metric we use to examine the relationship between income and a number of financial variables is a variance decomposition. As noted there, variance decompositions have the advantage that they measure the predictive power of orthogonalized residuals. They also, of course, have some well-known disadvantages (see foot note $^{2}$ ).

Tables 7, 8 and 9 show variance decomposition s of nominal GDP, real GDP and inflation. These variance decompositions are based on a subset of the VARs used for the Granger tests in Tables 4-6. The results shown include the M4 aggregate. (Variance decompositions for the same systems using the $M 2$ aggregate are shown in Tables A10-A12 of the Appendix, available from authors on request.) The 
choice of the monetary aggregate does not significantly affect our conclusions. Variance decompositions are computed from VARs including and excluding a deterministic time trend. The ordering of the variables in computing the variance decompositions is the same as that of the column headings. The cells in the table show the percentage of the variance of the forecasted variable accounted for by variation in the column variable at an 8-quarter horizon. The variance decompositions are computed via Monte Carlo simulations with 500 draws. Figures given in parenthesis are standard errors from these simulations. Sample periods are the same as for Tables 4, 5 and 6 . Interest rate measures are the call rate $\left(R_{\mathrm{C}}\right)$ call rate-bill rate spread $\left(R_{\mathrm{C}}-R_{\mathrm{B}}\right)$ and loan rate-bill rate spread $\left(R_{\mathrm{L}}-R_{\mathrm{B}}\right)$. We consider each of the three goal variables $(G D P, R G D P$ and $\dot{P})$ in turn.

Nominal GDP. The most robust result in Table 7 is that the $M 4$ aggregate explains a large percentage of the forecast variance in GDP in the post 1979 period. For each interest rate (or spread) included and whether or not the trend term is included, M4 explains over $40 \%$ of the forecast variance in nominal GDP, a proportion that is significantly different from zero at the $5 \%$ level. $M 4$ has no significance in the earlier period or full sample. None of the interest rates or

Table 7. Variance decompositions for nominal GDP

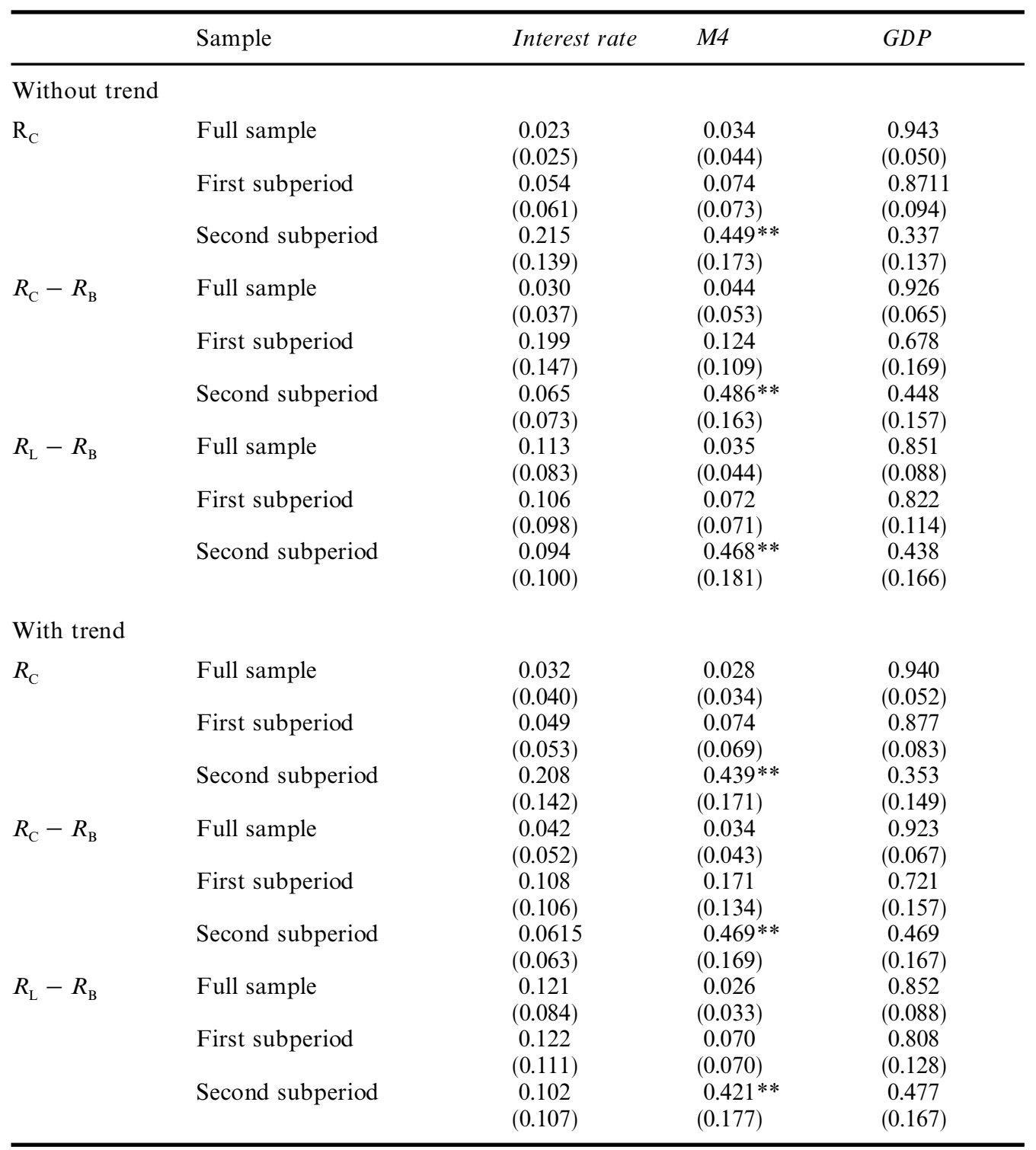

*Indicates significance at $10 \%$ level.

**Indicates significance at 5\% level. Stars are shown only for money and interest rate (or interest rate spread) variables not for income. 
Table 8. Variance decompositions for real GDP

\begin{tabular}{|c|c|c|c|c|c|}
\hline & Sample & Interest rate & M4 & $R G D P$ & $\dot{P}$ \\
\hline \multicolumn{6}{|c|}{ Without trend } \\
\hline \multirow[t]{4}{*}{$R_{\mathrm{C}}$} & Full sample & $\begin{array}{l}0.279 * * \\
(0.13)\end{array}$ & $\begin{array}{c}0.087 \\
(0.074)\end{array}$ & $\begin{array}{c}0.613 \\
(0.127)\end{array}$ & $\begin{array}{c}0.021 \\
(0.028)\end{array}$ \\
\hline & First subperiod & $\begin{array}{c}0.254 \\
(0.153)\end{array}$ & $\begin{array}{c}0.149 \\
(0127)\end{array}$ & $\begin{array}{c}0.469 \\
(0.152)\end{array}$ & $\begin{array}{l}0.128 \\
(0104)\end{array}$ \\
\hline & \multirow[t]{2}{*}{ Second subperiod } & 0.054 & $0.565 * *$ & 0.278 & 0.102 \\
\hline & & $(0.066)$ & $(0.154)$ & $(0.130)$ & $(0.075)$ \\
\hline \multirow{6}{*}{$R_{\mathrm{C}}-R_{\mathrm{B}}$} & \multirow{2}{*}{ Full sample } & 0.091 & 0.060 & 0.829 & 0.019 \\
\hline & & $(0.08)$ & $(0.66)$ & $(0.099)$ & $(0.025)$ \\
\hline & \multirow[t]{2}{*}{ First subperiod } & $0.324 * *$ & 0.093 & 0.549 & 0.033 \\
\hline & & $(0.155)$ & $(0.091)$ & $(0.155)$ & $(0.034)$ \\
\hline & \multirow[t]{2}{*}{ Second subperiod } & 0.055 & $0.465 * *$ & 0.284 & 0.197 \\
\hline & & $(0.065)$ & $(0.163)$ & $(0.136)$ & $(0.138)$ \\
\hline \multirow[t]{6}{*}{$R_{\mathrm{L}}-R_{\mathrm{B}}$} & \multirow[t]{2}{*}{ Full sample } & 0.049 & 0.102 & 0.828 & 0.020 \\
\hline & & $(0.048)$ & $(0.089)$ & $(0.102)$ & $(0.25)$ \\
\hline & \multirow[t]{2}{*}{ First subperiod } & 0.102 & $0.264 *$ & 0.558 & 0.076 \\
\hline & & $(0.073)$ & $(0.146)$ & $(0.155)$ & $(0.066)$ \\
\hline & \multirow[t]{2}{*}{ Second subperiod } & 0.068 & $0.536 * *$ & 0.287 & 0.108 \\
\hline & & $(0.074)$ & $(0.150)$ & $(0.131)$ & $(0.094)$ \\
\hline \multicolumn{6}{|c|}{ With trend } \\
\hline \multirow{6}{*}{$R_{\mathrm{C}}$} & \multirow[t]{2}{*}{ Full sample } & $0.301 * *$ & 0.035 & 0.646 & 0.018 \\
\hline & & $(0.129)$ & $(0.041)$ & $(0.125)$ & $(0.023)$ \\
\hline & \multirow[t]{2}{*}{ First subperiod } & 0.169 & 0.133 & 0.642 & 0.056 \\
\hline & & $(0.110)$ & $(0.103)$ & $(0.137)$ & $(0.053)$ \\
\hline & \multirow[t]{2}{*}{ Second subperiod } & 0.055 & $0.515 * *$ & 0.353 & 0.076 \\
\hline & & $(0.070)$ & $(0.168)$ & $(0.157)$ & $(0.064)$ \\
\hline \multirow{6}{*}{$R_{\mathrm{C}}-R_{\mathrm{B}}$} & \multirow[t]{2}{*}{ Full sample } & 0.041 & 0.050 & 0.884 & 0.025 \\
\hline & & $(0.051)$ & $(0.061)$ & $(0.084)$ & $(0.032)$ \\
\hline & \multirow[t]{2}{*}{ First subperiod } & 0.171 & 0.130 & 0.656 & 0.042 \\
\hline & & $(0.119)$ & $(0.114)$ & $(0.145)$ & $(0.040)$ \\
\hline & \multirow[t]{2}{*}{ Second subperiod } & 0.057 & $0.446 * *$ & 0.332 & 0.166 \\
\hline & & $(0.065)$ & $(0.168)$ & $(0.162)$ & $(0.126)$ \\
\hline \multirow[t]{6}{*}{$\mathrm{R}_{\mathrm{L}}-R_{\mathrm{B}}$} & \multirow[t]{2}{*}{ Full sample } & 0.032 & 0.054 & 0.886 & 0.027 \\
\hline & & $(0.036)$ & $(0.061)$ & $(0.886)$ & $(0.034)$ \\
\hline & \multirow[t]{2}{*}{ First subperiod } & $0.247^{*}$ & 0.169 & 0.529 & 0.055 \\
\hline & & $(0.128)$ & $(0.120)$ & $(0.148)$ & $(0.053)$ \\
\hline & \multirow[t]{2}{*}{ Second subperiod } & 0.062 & $0.492 * *$ & 0.353 & 0.093 \\
\hline & & $(0.070)$ & $(0.163)$ & $(0.165)$ & $(0.091)$ \\
\hline
\end{tabular}

*Indicates significance at $10 \%$ level.

**Indicates significance at 5\% level. Stars are shown only for money and interest rate variables not for income or inflation.

interest rate spreads included explains a statistically significant portion of GDP forecast variance for the whole period or either subperiod.

Real GDP. In Table 8, the most striking result is that the M4 aggregate explains a large fraction of the forecast variance of real GDP, in the second subperiod. Again this result is statistically significant at the $5 \%$ level in all specifications. ${ }^{13}$ In some specifications an interest rate (or interest rate spread) measure explains a statistically significant portion of real GDP variance, but in each case this is for the whole period or first subperiod.
Inflation. From the results in Table 9, it can be seen that both the M4 aggregate and each interest rate (or spread) measure explain a significant fraction of the forecast variance of inflation. The interest rate measure typically explains between 10 and $20 \%$ of the forecast variance of inflation and is significant at the $10 \%$ level in 16 of 18 specifications (at the 5\% level in 14) in the table. $M 4$ explains anywhere from $7-8 \%$ to $18-20 \%$ of the forecast variance of inflation and is significant at the $10 \%$ level in all 18 specifications (at the 5\% level in 14). ${ }^{14}$

Both interest rate measures and the monetary aggregate appear to have a robust relationship with the inflation rate

\footnotetext{
${ }^{13}$ The same holds true for the M2 aggregate.

${ }^{14}$ The M2 aggregate is significant in all 18 specifications.
} 
Table 9. Variance decompositions for inflation

\begin{tabular}{|c|c|c|c|c|c|}
\hline & Sample & Interest rate & M4 & $R G D P$ & $\dot{P}$ \\
\hline \multicolumn{6}{|c|}{ Without trend } \\
\hline$R_{\mathrm{C}}$ & $\begin{array}{l}\text { Full sample } \\
\text { First subperiod } \\
\text { Second subperiod }\end{array}$ & $\begin{array}{l}0.125^{* *} \\
(0.051) \\
0.234 * * \\
(0.090) \\
0.190 * * \\
(0.071)\end{array}$ & $\begin{array}{l}0.072 * \\
(0.040) \\
0.153 * * \\
(0.061) \\
0.137 * * \\
(0.064)\end{array}$ & $\begin{array}{c}0.096 \\
(0.043) \\
0.101 \\
(0.055) \\
0.153 \\
(0.073)\end{array}$ & $\begin{array}{c}0.707 \\
(0.065) \\
0.512 \\
(0.099) \\
0.520 \\
(0.095)\end{array}$ \\
\hline$R_{\mathrm{C}}-R_{\mathrm{B}}$ & $\begin{array}{l}\text { Full sample } \\
\text { First subperiod } \\
\text { Second subperiod }\end{array}$ & $\begin{array}{l}0.160 * * \\
(0.072) \\
0.333 * * \\
(0.108) \\
0.116 \\
(0.069)\end{array}$ & $\begin{array}{c}0.091 * * \\
(0.046) \\
0.156 * * \\
(0.072) \\
0.130 * \\
(0.067)\end{array}$ & $\begin{array}{c}0.146 \\
(0.063) \\
0.159 \\
(0.073) \\
0.158 \\
(0.068)\end{array}$ & $\begin{array}{c}0.603 \\
(0.080) \\
0.352 \\
(0.089) \\
0.595 \\
(0.103)\end{array}$ \\
\hline$R_{\mathrm{L}}-R_{\mathrm{B}}$ & $\begin{array}{l}\text { Full sample } \\
\text { First subperiod } \\
\text { Second subperiod }\end{array}$ & $\begin{array}{c}0.146 * * \\
(0.065) \\
0.2 * * \\
(0.087) \\
0.153 * \\
(0.082)\end{array}$ & $\begin{array}{c}0.082 * * \\
(0.040) \\
0.181 * * \\
(0.066) \\
0.120 * \\
(0.066)\end{array}$ & $\begin{array}{c}0.136 \\
(0.064) \\
0.111 \\
(0.058) \\
0.133 \\
(0.065)\end{array}$ & $\begin{array}{c}0.635 \\
(0.077) \\
0.508 \\
(0.092) \\
0.595 \\
(0.103)\end{array}$ \\
\hline With tren & & & & & \\
\hline$R_{\mathrm{C}}$ & $\begin{array}{l}\text { Full sample } \\
\text { First subperiod } \\
\text { Second subperiod }\end{array}$ & $\begin{array}{l}0.124 * * \\
(0.053) \\
0.181 * * \\
(0.078) \\
0.194 * * \\
(0.078)\end{array}$ & $\begin{array}{l}0.075 * * \\
(0.037) \\
0.212 * * \\
(0.076) \\
0.145 * * \\
(0.068)\end{array}$ & $\begin{array}{c}0.097 \\
(0.045) \\
0.160 \\
(0.065) \\
0.146 \\
(0.071)\end{array}$ & $\begin{array}{c}0.703 \\
(0.069) \\
0.447 \\
(0.091) \\
0.516 \\
(0.096)\end{array}$ \\
\hline$R_{\mathrm{C}}-R_{\mathrm{B}}$ & $\begin{array}{l}\text { Full sample } \\
\text { First subperiod } \\
\text { Second subperiod }\end{array}$ & $\begin{array}{c}0.154 * * \\
(0.070) \\
0.192 * * \\
(0.084) \\
0.101 \\
(0.061)\end{array}$ & $\begin{array}{c}0.096 * * \\
(0.047) \\
0.175 * * \\
(0.076) \\
0.155^{* *} \\
(0.079)\end{array}$ & $\begin{array}{c}0.156 \\
(0.065) \\
0.231 \\
(0.086) \\
0.147 \\
(0.065)\end{array}$ & $\begin{array}{c}0.595 \\
(0.083) \\
0.401 \\
(0.091) \\
0.597 \\
(0.098)\end{array}$ \\
\hline$R_{\mathrm{L}}-R_{\mathrm{B}}$ & $\begin{array}{l}\text { Full sample } \\
\text { First subperiod } \\
\text { Second subperiod }\end{array}$ & $\begin{array}{c}0.153 * * \\
(0.068) \\
0.148 * * \\
(0.070) \\
0.148 * \\
(0.083)\end{array}$ & $\begin{array}{c}0.085 * * \\
(0.041) \\
0.18 * * \\
(0.068) \\
0.136 * \\
(0.077)\end{array}$ & $\begin{array}{c}0.133 \\
(0.059) \\
0.141 \\
(0.059) \\
0.120 \\
(0.058)\end{array}$ & $\begin{array}{c}0.628 \\
(0.079) \\
0.531 \\
(0.092) \\
0.596 \\
(0.107)\end{array}$ \\
\hline
\end{tabular}

*Indicates significance at $10 \%$ level.

**Indicates significance at 5\% level. Stars are shown only for money and interest rate variables not for income and inflation.

as measured by the metric of variance decompositions, for the whole period and both subperiods.

\section{SUMMARY AND POLICY IMPLICATIONS}

\section{Summary}

We have examined the relationship between a number of financial variables and traditional monetary policy goals. With respect to nominal GDP, our variance decomposi- tions suggest that a monetary aggregate (M2 or M4) would be a good information variable (or intermediate target) based on evidence from the post-1979 period. We do not, however, find strong evidence of a Granger causal relationship for either monetary aggregate for this subperiod.

Results for real GDP and the inflation rate are more robust. For real GDP in the post-1979 period, both the results of Granger tests and variance decompositions suggest that both monetary aggregates (M2 and M4) are good information (or intermediate target) variables. Here, our United Kingdom results are in contrast to Friedman and Kuttner's (1992) results for the United States which 
show a breakdown in the money-income relationship in the 1980s.

Because UK monetary policy has followed a strategy of targeting inflation in the period since 1992, our inflation results are perhaps of most interest. There is a robust relationship between inflation and both interest rates $\left(R_{\mathrm{B}}, R_{\mathrm{C}}\right)$ that we considered. The interest rate measures are strongly Granger causal and explain a significant fraction of the forecast variance of inflation. ${ }^{15}$ These results are robust across the subperiods we consider. Interest rate spreads are also significant in variance decompositions, but there is less evidence that they are Granger causal with respect to inflation.

Both monetary aggregates are significant in variance decompositions in the post-1979 subperiod. Granger causality tests also show a significant relationship between $M 2$ and inflation in this subperiod, as well as in the earlier one. Evidence of Granger causality from M4 to inflation is less clear - its significance depending on whether or not a trend is included in the VAR.

\section{Policy implications}

The finding that broader monetary aggregates are informative with respect to monetary policy goal variables in the post-1979 period is at odds with the conventional view; which view holds that broad aggregates have been unreliable predictors of both nominal and real GDP since 1979 . This discrepancy suggests the usefulness of further examination of the money- income relationship during these years.

Figures 1 and 2 show plots of the growth rates in $M 4$ and, respectively, nominal and real GDP. While statements about such graphs are necessarily imprecise, it appears to us that instability in the money-income relationship is most apparent in the early 1980s. From the mid-1980s the series have many periods of positive co-movement. It appears a possibility, therefore, that the conventional view is based on the experience of the early 1980s. Figures 3 and 4 plot impulse response functions to a shock to $M 4$. The figures show substantial positive responses of both nominal and real GNP to innovations in M4 (all variables measured in natural logs). Figure 4, however, does not indicate a significant response of inflation to innovations in $M 4 .^{16}$

The plots in Figs 1-4 are on the whole supportive of the view that monetary aggregates have been informative with respect to monetary goal variables in the post-1979 period - an essential qualification for a financial variable to be a useful information variable.

As explained in Section II, however, a financial variable may be informative without being truly causal, or structural,

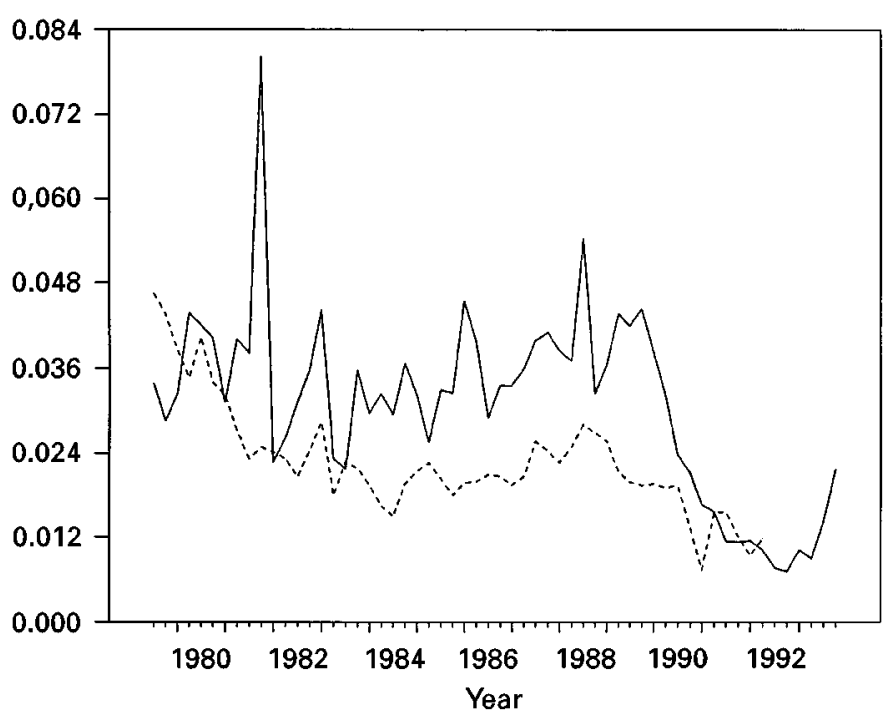

Fig. 1. M4 (-) and GDP (---) growth rates for the second subperiod

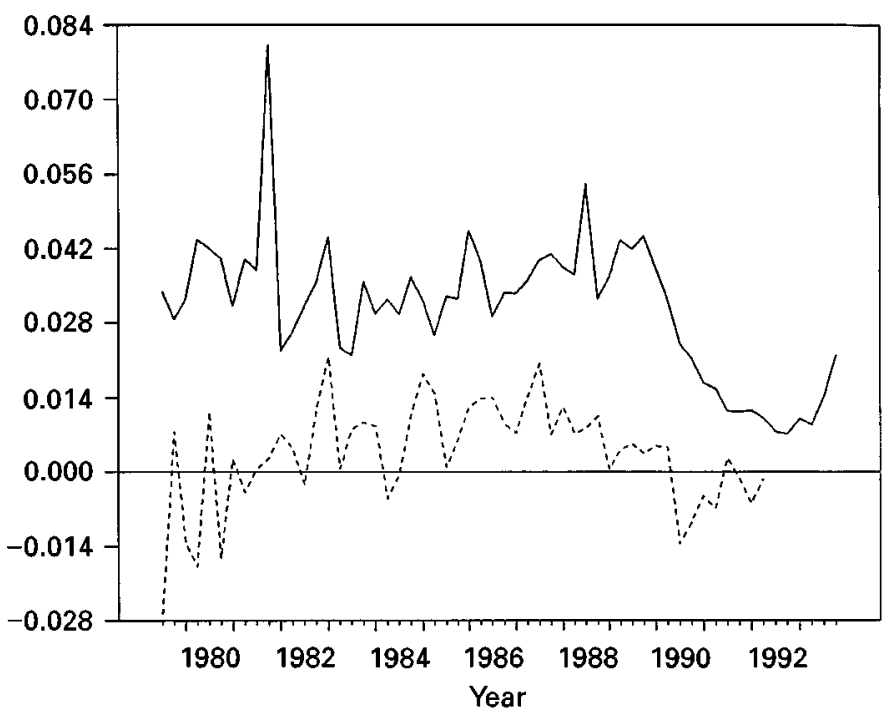

Fig. 2. M4 (-) and RGDP (---) growth rates for the second subperiods

in the sense of Bernanke (1993). If the financial variable is chosen as an intermediate target a relationship with the policy goal variable, due for example to reverse causation or mutual causation from some other variable, may breakdown. To examine further the nature of the relationship between income and monetary aggregates, we consider Granger tests of the effect of GDP on M2 and M4. Table 10

\footnotetext{
${ }^{15}$ The variance decompositions shown in the text are only for the call rate $\left(R_{\mathrm{C}}\right)$. Results substituting the treasury bill rate $\left(R_{\mathrm{B}}\right)$ produce very similar results.

${ }^{16}$ For simplicity, the figures do not show confidence intervals. Computed confidence intervals for these impulse response functions indicate that the responses of GDP and RGDP are significantly different from zero for 12 and 6 quarters, respectively.
} 


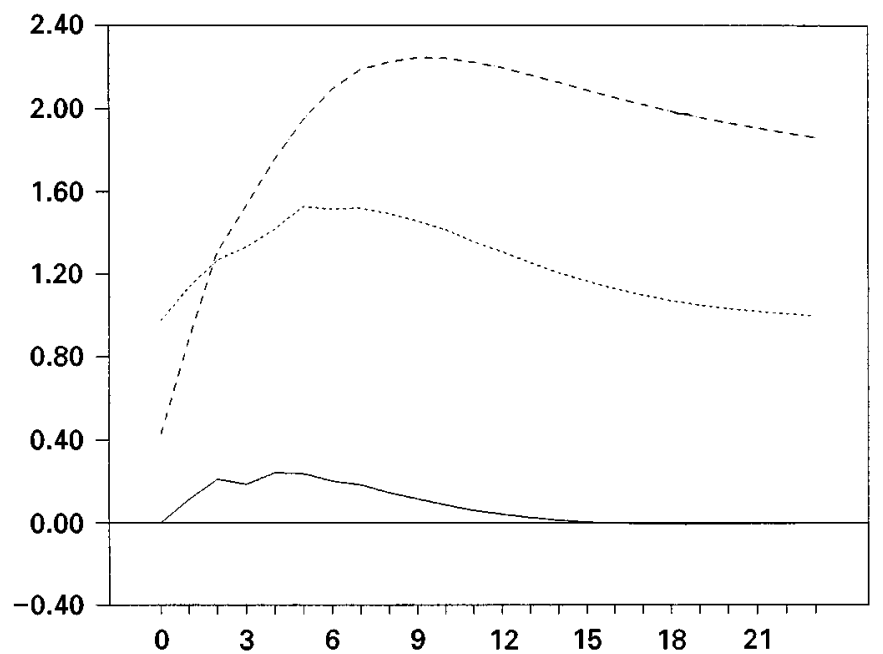

Fig. 3. Responses to M4: call rate (-), M4 (............) and GDP $(---)$

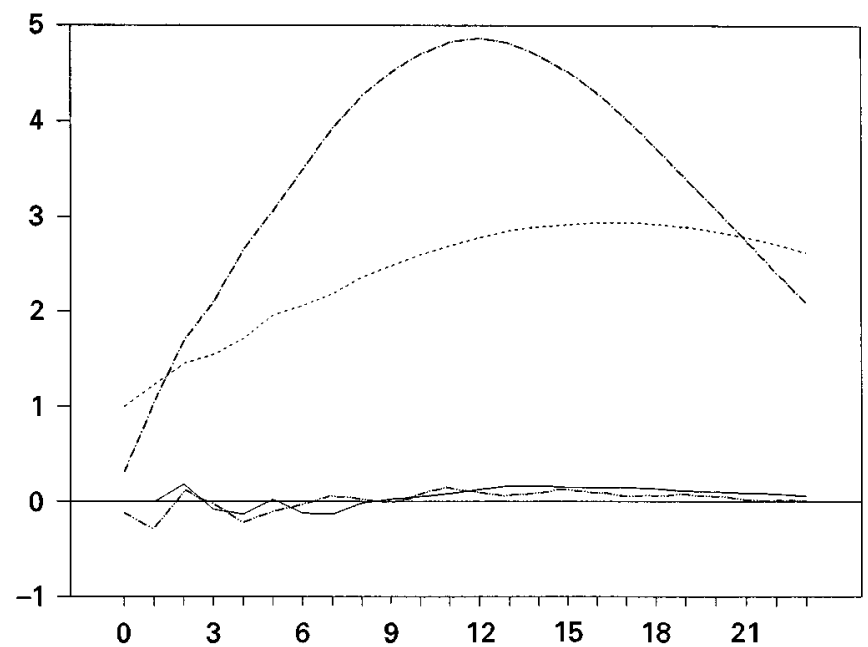

Fig. 4. Responses to M4: call rate (-), M4 (............), Real GDP $(-\cdot-\cdot)$, inflation $(-\cdot-\cdot-)$

shows marginal significance levels ( $p$-values) for the effects GDP on $M 2$ and $M 4$ in the same estimated VARS for which results are shown in Table $4 .{ }^{17}$ Results are for the second subperiod. GDP is seen to have significant predictive power with respect to both monetary aggregates. Figure 5 shows an impulse response function for the effect on $M 4$ of an innovation to GDP. M4 shows a strong positive response again consistent with causality from GDP to money.

Our results in this section indicate that the money-income relationship is one of feedback, rather than of onedirectional causality from money to income. ${ }^{18}$ If this is the

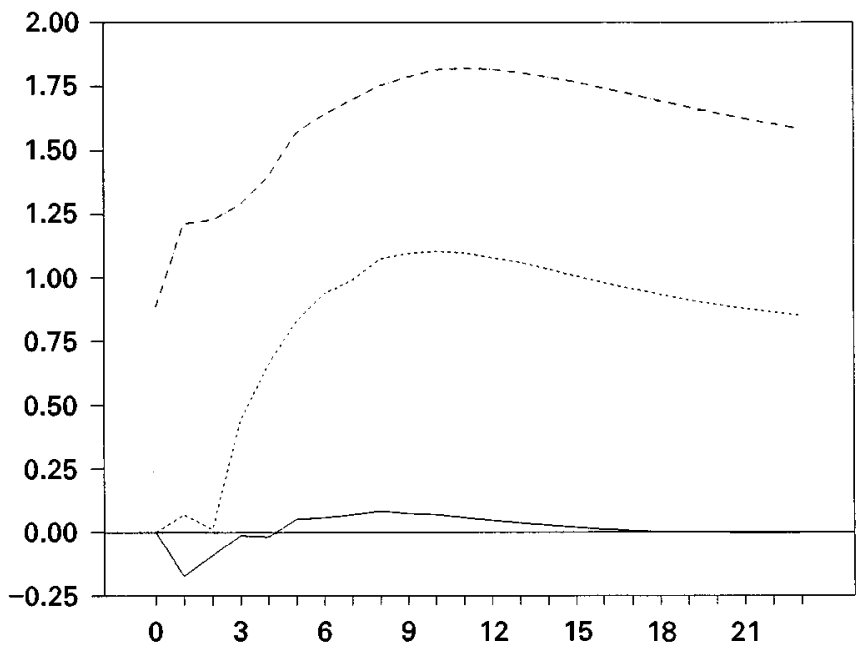

Fig. 5. Responses to GDP: call rate (—), M4 (...........), GDP (- - - $)$

Table 10. Marginal significance levels (p-values): Granger causality from GDP to monetary aggregates

\begin{tabular}{lll}
\hline & $M 2$ & $M 4$ \\
\hline With trend & 0.050 & 0.004 \\
Without trend & 0.037 & 0.005 \\
\hline
\end{tabular}

case our overall results are more supportive of a role for a monetary aggregate as an information variable rather than an intermediate target.

\section{CONCLUSION}

Our results were summarized in the previous section. Here we have only a concluding comment.

Friedman (1993, p. 182) argues that 'once the policymaking procedure is framed in terms of information variables, rather than an intermediate target, there is no reason why interest rate relationships are any less suitable for this purpose than monetary aggregates.' Our results indicate that for the United Kingdom interest rates are informative with respect to monetary policy goals. Our results also indicate that broad monetary aggregates are also potentially useful as information variables.

\section{REFERENCES}

Bernanke, B. S. (1993) How important is the credit channel in the transmission of monetary policy?: A comment, CarnegieRochester Conference Series on Public Policy, 39, 47-52. 
Bernanke, B. S. and Blinder, A. S. (1992) The Federal funds rate and the channels of monetary transmission, American Economic Review, 82, 901-21.

Chrystal, K. A. and McDonald, R. (1994) Empirical evidence on the recent behavior and usefulness of simple-sum and weighted measures of the money stock, Federal Reserve Bank of St. Louis Review, 76, 73-109.

Engle, R. A. and Granger, C. W. J. (1987) Cointegration and error correction: Representation, estimation, and testing, Econometrica, 55, 251-76.

Feldstein, M. and Stock, J. H. (1994) The use of a monetary aggregate to target nominal GDP, in N. G. Mankiw (ed.) Monetary Policy, University of Chicago Press, Chicago, IL.

Friedman, B. M. (1993) The role of judgment and discretion in the conduct of monetary policy, in Changing Capital Markets: Implications for Monetary Policy, Federal Reserve Bank of Kansas City.

Friedman, B. M. and Kuttner, K. N. (1992) Money, income, and interest rates, American Economic Review, 82, 472-92.

Friedman, B. M. and Kuttner, K. N. (1993) Another look at the evidence on money-income causality, Journal of Econometrics, 57, 189-203.

Friedman, B. M. and Schwartz, A. (1982) Monetary Trends in the United States and the United Kingdom, University of Chicago Press, Chicago, IL.

Harvey, A. (1990) The Econometric Analysis of Time Series, Philip Allan, Oxford.

Hansen, H. and Juselius, K. (1995) Cats in Rats Cointegration Analysis of Time Series, Estina, Evanston, IL.

Johansen, S. (1991) Estimation and hypothesis testing of cointegrating vectors in Gaussian vector autoregressive models, Econometrica, 59, 1551-80.
Johansen, S. and Juselius, K. (1992) Maximum likelihood estimation and inference on cointegration-with application to the demand for money, Oxford Bulletin of Economics and Statistics, 52, 169-209.

King, R. G., Plosser, C.I., Stock, J. H. and Watson, M. W. (1991) Stochastic trends and economic fluctuations, American Economic Review, 81, 819-40.

Moersch, M. (1996) On the predictive power of interest rate spreads for output, Journal of Economics and Business, 48, 185-99.

Phillips, P. C. B. and Ouliars, S. (1990) Asymptotic properties of residual based tests for cointegration, Econometrica, 58, 165-93.

Phillips, P. C. B. and Perron, P. (1988) Testing for a unit root in time series regression, Biometrika, 75, 335-46.

Ramey, V. (1993) How important is the credit channel in the transmission of momentary policy?, Carnegie-Rochester Conference Series on Public Policy, 39, 1-45.

Sims, C. A. (1992) Interpreting the macroeconomic time series facts, European Economic Review, 36, 975-1011.

Sims, C. A., Stock, J. H. and Watson, M. W. (1990) Inference in linear systems time series models with some unit roots, Econometrica, 58, 113-44.

Stock, J. H. and Watson, M. W. (1988) Testing for common trends, Journal of the American Statistical Association, 83, 1097-107.

Stock, J. H. and Watson, M. W. (1989) Interpreting the evidence on money-income causality, Journal of Econometrics, 40, $161-81$.

Stock, J. H. and Watson, M. W. (1993) A simple estimator of cointegrating vectors in higher order integrated systems, Econometrica, 61, 783-920. 